\title{
A New Approach to Producing Functional Ga Subunits Yields the Activated and Deactivated Structures of $\mathrm{Ga}_{12 / 13}$ Proteins †
}

\author{
Barry Kreutz ${ }^{\ddagger}$, Douglas M. Yau ${ }^{\ddagger}$, Mark Nance ${ }^{\S}$, Shihori Tanabe ${ }^{\ddagger}$, John J. G. Tesmer ${ }^{\star}{ }^{\star}$, and \\ Tohru Kozasa $\neq,{ }^{*}$ \\ Department of Pharmacology, Life Sciences Institute, The University of Michigan, 210 Washtenaw \\ Ave, Ann Arbor, Michigan 48109-2216
}

\section{Summary}

The oncogenic $\mathrm{G}_{12 / 13}$ subfamily of heterotrimeric $\mathrm{G}$ proteins transduces extracellular signals that regulate the actin cytoskeleton, cell cycle progression, and gene transcription. Previously, structural analyses of fully-functional $\mathrm{G \alpha}_{12 / 13}$ subunits have been hindered by insufficient amounts of homogeneous, functional protein. Herein we report that substitution of the N-terminal helix of $\mathrm{G} \alpha_{\mathrm{i} 1}$ for the corresponding region of $\mathrm{G} \alpha_{12}$ or $\mathrm{G} \alpha_{13}$ generated soluble chimeric subunits $\left(\mathrm{G} \alpha_{\mathrm{i} / 12}\right.$ and $\mathrm{G \alpha}_{\mathrm{i} / 13}$ ) that could be purified in sufficient amounts for crystallographic studies. Each chimera bound guanine nucleotides, G $\beta \gamma$ subunits and effector proteins, and exhibited GAP responses to p115RhoGEF and leukemia-associated RhoGEF. Like their wild-type counterparts, $\mathrm{G \alpha}_{\mathrm{i} / 13}$, but not $\mathrm{G} \alpha_{\mathrm{i} / 12}$, stimulated the activity of $\mathrm{p} 115 \mathrm{RhoGEF}$. Crystal structures of the $\mathrm{G} \alpha_{\mathrm{i} / 12} \cdot \mathrm{GDP} \cdot \mathrm{AlF}_{4}{ }^{-}$and $\mathrm{G} \alpha_{\mathrm{i} / 13}$. GDP complexes were determined using diffraction data extending to 2.9 and $2.0 \AA$, respectively. These structures reveal not only the native structural features of $\mathrm{G} \alpha_{12}$ and $\mathrm{G} \alpha_{13}$ subunits, which are expected to be important for their interactions with GPCRs and effectors such as G $\alpha$ regulated RhoGEFs, but also novel conformational changes that are likely coupled to GTP hydrolysis in the $\mathrm{G} \alpha_{12 / 13}$ class of heterotrimeric $\mathrm{G}$ proteins.

Heterotrimeric GTP-binding proteins (G proteins) receive inputs from $\mathrm{G}$ protein-coupled receptors (GPCRs) at the cell surface and elicit a wide variety of responses within the cell (1). Activation of GPCRs by extracellular stimuli induces the $\mathrm{G} \alpha$ subunit to release its bound GDP and bind GTP, and facilitates dissociation of Ga.GTP from the $\beta$ and $\gamma$ subunits (G $\beta \gamma$ ). Both $\mathrm{G} \alpha \cdot \mathrm{GTP}$ and $\mathrm{G} \beta \gamma$ subsequently bind to and regulate the activity of various effector molecules. A family known as regulator of $\underline{G}$ protein signaling (RGS) proteins can bind to activated $\mathrm{G} \alpha$ subunits and accelerate their rate of deactivation, thereby serving as GTPaseactivating proteins (GAPs) (2). It was shown through biochemical and structural studies of RGS4 that its core helical domain, referred to herein as the RGS homology (RH) domain ${ }^{1}$, binds to all three switch regions of $\mathrm{G} \alpha$ and thereby stabilizes the transition state for GTP hydrolysis $(3,4)$.

\footnotetext{
${ }^{\dagger}$ Support was provided by National Institute of Health Grant HL071818, American Heart Association Scientist Development Grant 0235273N and an American Cancer Society Research Scholar grant (to JJGT), National Institutes of Health Grants GM61454 and NS41441 and an American Heart Established Investigator Award 0040006N (to TK) and a Predoctoral fellowship from the American Heart Association Midwest Affiliate 0315253Z (to BK)

*To whom correspondence should be addressed. E-mail: E-mail: johntesmer@umich.edu. Telephone: (734) 615-9544. Fax: (734) 763-6492. E-mail: tkozas@uic.edu. Telephone: (312)-413-0111. FAX: (312)-996-1225.

*Department of Pharmacology, University of Illinois \& College of Medicine, Chicago, IL 60612

\$Institute for Cell and Molecular Biology, Department of Chemistry and Biochemistry, University of Texas, Austin, TX 78712;

Department of Pharmacology, Life Sciences Institute, University of Michigan, Ann Arbor MI 48109.

${ }^{1}$ We refer to the core domain of RGS4 as an RGS homology (RH) domain in order to distinguish between the fold of this domain and its function. For example, while RGS proteins serve as Ga GAPs, domains in G protein-coupled receptor kinases and axin that are homologous to those found in RGS proteins (RH domains) have distinct functions.
} 
Among the four subfamilies of $\mathrm{G} \alpha$ subunits (5), the members of the $\mathrm{G} \alpha_{12 / 13}$ subfamily are distinct in that they are potently oncogenic in cell-based assays $(6,7)$. Stimulation of $\mathrm{G} \alpha_{12 / 13^{-}}$ coupled receptors, such as those for thrombin or lysophosphatidic acid, transforms cells in a manner implicating the activation of Rho family GTPases $(8,9)$. Downstream effector targets of $\mathrm{G} \alpha_{12 / 13}$ subunits are diverse and include cadherin (10), protein phosphatase 5 (11) and many others (12). However, the best-characterized targets of $\mathrm{G} \alpha_{12 / 13}$ subunits are a family of Rho guanine nucleotide exchange factors (RhoGEFs), including p115RhoGEF, leukemiaassociated RhoGEF (LARG), and PDZ-RhoGEF (13-15). Each of these RhoGEFs contains an RH domain (also known as the rgRGS or LH domain) ${ }^{1}$ that binds specifically to activated $\mathrm{G}_{12 / 13}$ subunits (16). Unlike RGS proteins, the RhoGEF RH domain binds to the effectorbinding site of the $\mathrm{G} \alpha$ subunit rather than the site traditionally used by RGS proteins (17). A small, acidic domain N-terminal to the RH domain, which is essential for GAP activity but not for the binding of $\mathrm{G \alpha}_{13}(18,19)$, occupies the binding site traditionally used by RGS proteins.

Biochemical and crystallographic characterization of $\mathrm{G}_{12 / 13}$ subunits and their effector complexes requires large amounts of homogeneous, fully-functional $\mathrm{G} \alpha_{12}$ and $\mathrm{G} \alpha_{13}$ subunits, which previously have been produced with exceptionally low yields $(20,21)$. Although Chen et al. were able to express a " $\mathrm{G} \alpha_{13 / i}-5$ " chimera, in which the switch regions and $\alpha$-helical domain of $\mathrm{G} \alpha_{13}$ were swapped for those of $\mathrm{G} \alpha_{\mathrm{i} 1}$, the resulting chimera exhibited approximately a 10-fold higher nucleotide exchange rate and $5 \%$ of the GAP activity of wild-type $\mathrm{G}_{13}$ in response to $115 \mathrm{RhoGEF}$. Even so, it could still be crystallized as a complex with an $\mathrm{N}$-terminal fragment of p115RhoGEF that included its RH domain (17).

Herein we show that substitution of the $\mathrm{N}$-terminal helix of $\mathrm{G} \alpha_{\mathrm{i} 1}$ for the corresponding region of $\mathrm{G \alpha}_{12}$ and $\mathrm{G} \alpha_{13}$ generated soluble $\mathrm{G \alpha}_{\mathrm{i} / 12}$ and $\mathrm{G \alpha}_{\mathrm{i} / 13}$ chimera that retained all wild-type biochemical properties while also being expressed at much greater levels than their wild-type counterparts. By determining the crystal structures of the $\mathrm{Go}_{\mathrm{i} / 12} \cdot \mathrm{GDP} \cdot \mathrm{AlF}_{4}{ }^{-}$(activated) and $\mathrm{Go}_{\mathrm{i} / 13}$. GDP (deactivated) complexes, we not only show that these proteins are suitable for structural studies, but also provide the first look at the native atomic structures of these oncogenic $\mathrm{G}$ protein subunits and a novel conformational change upon deactivation of these subunits that we propose is specific to the $\mathrm{G} \alpha_{12 / 13}$ subfamily. Differences in the structures of $\mathrm{G} \alpha_{12}$ and $\mathrm{G} \alpha_{13}$ undoubtedly contribute to their differential ability to couple with receptors and to regulate downstream effectors.

\section{Experimental Procedures}

\section{Expression constructs}

$\mathrm{The}_{\mathrm{G}} \mathrm{\alpha}_{\mathrm{i} / 13}$ chimera was created by ligating the $\mathrm{N}$-terminal coding region of rat $\mathrm{G \alpha}_{\mathrm{i}}$ (residues 1-28) to $\mathrm{G} \alpha_{13}$ (residues 47-377) and subcloning the product into the baculovirus transfer vector pFastBacHT $_{\mathrm{A}}$ (Invitrogen, Carlsbad, CA). A construct of $\mathrm{Ga}_{\mathrm{i} / 12}$ was created using the same strategy. Each construct therefore includes an $\mathrm{N}$-terminal hexahistidine $\left(\mathrm{His}_{6}\right)$ tag followed by a tobacco etch virus (TEV) protease recognition site. The expression construct for glutathione$S$-transferase (GST)-p115-RH or GST-LARG-RH was generated by subcloning the coding region of p115RhoGEF (residues 1 to 252) or LARG (residues 319 to 598) into pGEX-KG, respectively.

\section{Production of chimeric Ga subunits}

All purification steps were conducted at $4^{\circ} \mathrm{C}$ using ice-cold buffers supplemented with protease inhibitors. Cells from 4 liters of Sf9 culture were harvested $48 \mathrm{~h}$ after infection with $15 \mathrm{ml} / \mathrm{L}$ of either $\mathrm{G \alpha}_{\mathrm{i} / 13}$ or $\mathrm{G \alpha}_{\mathrm{i} / 12}$ amplified baculovirus stock, resuspended in $400 \mathrm{ml}$ of Lysis Buffer (20 mM HEPES pH 8.0, 0.1 mM EDTA, $10 \mathrm{mM}$ 2-mercaptoethanol ( $\beta \mathrm{ME}), 1 \mathrm{mM} \mathrm{MgCl} 2$, $100 \mathrm{mM} \mathrm{NaCl}$, and $10 \mu \mathrm{M} \mathrm{GDP}$ ), and then lysed by nitrogen cavitation. Lysates were 
centrifuged at $100,000 \times g$ for $30 \mathrm{~min}$, after which the supernatants were diluted with $1600 \mathrm{ml}$ of Buffer A (20 mM HEPES pH 8.0, $10 \mathrm{mM} \beta \mathrm{ME}, 1 \mathrm{mM} \mathrm{MgCl} 2,100 \mathrm{mM} \mathrm{NaCl}, 10 \mu \mathrm{M}$ GDP, and $12.5 \mathrm{mM}$ imidazole, $\mathrm{pH}$ 8.0) and loaded onto a Ni-NTA agarose (Qiagen, Valencia, CA) column equilibrated with Buffer A. The column was washed with 20 volumes of Buffer B

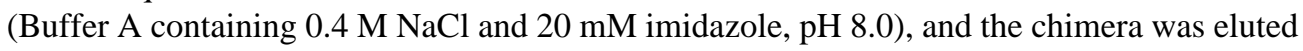
in 10 fractions of 1 volume of Buffer C (Buffer A containing $150 \mathrm{mM}$ imidazole, $\mathrm{pH}$ 8.0). Peak fractions were supplemented with $10 \%$ glycerol, and exchanged to Buffer D (20 mM HEPES $\mathrm{pH}$ 8.0, $10 \mathrm{mM} \beta \mathrm{ME}, 1 \mathrm{mM} \mathrm{MgCl} 2,100 \mathrm{mM} \mathrm{NaCl}, 10 \mu \mathrm{M} \mathrm{GDP}, 10 \%$ glycerol) with Centricon Plus-20 PL-30 (Millipore, Billerica, MA).

\section{Purification of RH proteins}

GST-p115-RH was produced in JM109 harboring pGEX-KG/p115-RH and pT-Trx plasmids (22) for $3 \mathrm{hr}$ after induction with $0.1 \mathrm{mM}$ IPTG at $30^{\circ} \mathrm{C}$. GST-LARG-RH was similarly expressed in BL21(DE3) CodonPlus RP (Stratagene, La Jolla, CA) harboring the pGEX-KG/ LARG-RH plasmid. GST-RH fusions were purified by glutathione Sepharose 4B resin (Amersham Biosciences).

\section{Interaction of chimeric $\mathrm{G} \alpha$ subunits with $\mathrm{RH}$ proteins}

$\mathrm{G \alpha}_{\mathrm{i} / 13}$ or $\mathrm{G} \alpha_{\mathrm{i} / 12}(2 \mu \mathrm{g})$ was diluted in Buffer $\mathrm{E}$ (20 mM Tris-HCl, $\mathrm{pH}$ 8.0, 1 mM EDTA, 10 $\mathrm{mM} \beta \mathrm{ME}, 300 \mathrm{mM} \mathrm{NaCl}, 10 \mathrm{mM} \mathrm{MgCl} 2,30 \mu \mathrm{M}$ GDP, $0.1 \% \mathrm{C}_{12} \mathrm{E}_{10}$ ), either in the absence or presence of $\mathrm{AlF}_{4}^{-}\left(30 \mu \mathrm{M} \mathrm{AlCl}_{3}\right.$ and $\left.10 \mathrm{mM} \mathrm{NaF}\right)$, and mixed with $33 \mu \mathrm{g}$ of GST-p115$\mathrm{RH}$ or $38 \mu \mathrm{g}$ of GST-LARG-RH in a final volume of $500 \mu \mathrm{l}$. After incubation on ice for 20 min, glutathione Sepharose 4B $(30 \mu \mathrm{l}$ resin) was added and samples were incubated with constant mixing for $1 \mathrm{~h}$ at $4^{\circ} \mathrm{C}$. Beads were pelleted by centrifugation $\left(600 \times g, 1 \mathrm{~min}, 4^{\circ} \mathrm{C}\right)$ and washed four times with $400 \mu \mathrm{l}$ of Buffer $\mathrm{E}$ (with or without $\mathrm{AlF}_{4}{ }^{-}$). Beads were mixed with $20 \mathrm{mM}$ reduced glutathione and SDS-PAGE sample buffer and boiled for $10 \mathrm{~min}$. Immunoblotting was performed with anti-G $\alpha_{13}$ B860 (21) or anti-G $\alpha_{12} \mathrm{~J} 168$ (20) antibody.

\section{Rho nucleotide exchange assays}

His $_{6}$-RhoA was expressed in Sf9 cells and purified as described (23). $\mathrm{G \alpha}_{13}, \mathrm{G} \alpha_{\mathrm{i} / 13}$, or $\mathrm{G} \alpha_{\mathrm{i} / 12}$ $(5 \mathrm{pmol})$ was first incubated in the presence of AMF $\left(60 \mu \mathrm{M} \mathrm{AlCl}_{3}, 5 \mathrm{mM} \mathrm{MgCl}_{2}\right.$, and $20 \mathrm{mM}$ $\mathrm{NaF}$ ) for $15 \mathrm{~min}$ on ice, then incubated with $\mathrm{His}_{6}-\mathrm{RhoA}(25 \mathrm{pmol})$ and p115RhoGEF $(0.25$ pmol) in binding buffer (50 mM Tris- $\mathrm{HCl}, \mathrm{pH} 7.5,1 \mathrm{mM}$ DTT, $0.5 \mathrm{mM}$ EDTA, $50 \mathrm{mM} \mathrm{NaCl}$, $5 \mathrm{mM} \mathrm{MgCl}_{2}, 0.05 \% \mathrm{C}_{12} \mathrm{E}_{10}$, and $10 \mu \mathrm{M} \mathrm{GTP} \gamma \mathrm{S}$ with $\left.\sim 500 \mathrm{cpm} / \mathrm{pmol}\left[{ }^{35} \mathrm{~S}\right]-\mathrm{GTP} \gamma \mathrm{S}\right)$ in a final reaction volume of $50 \mu$ l. Reactions were terminated after incubation for $5 \mathrm{~min}$ at $30^{\circ} \mathrm{C}$ by addition of wash buffer, and GTP $\gamma \mathrm{S}$ binding to RhoA was determined by filter binding as described (24).

\section{Crystallization of $\mathrm{Ga}_{\mathrm{i} / 12} \cdot \mathrm{GDP} \cdot \mathrm{AlF}_{\mathbf{4}}^{-}$and $\mathrm{Ga}_{\mathrm{i} / 13} \cdot \mathrm{GDP}$}

$\mathrm{G \alpha}_{\mathrm{i} / 13}$ or $\mathrm{G} \alpha_{\mathrm{i} / 12}$ was first incubated with $1.5 \%$ (w/w) recombinant TEV protease for $2 \mathrm{hr}$ at $25^{\circ}$ $\mathrm{C}$ to remove the $\mathrm{His}_{6}{ }^{-\mathrm{tag}}$, and then activated by $\mathrm{AlF}_{4}{ }^{-}\left(20 \mu \mathrm{M} \mathrm{AlCl}_{3}\right.$ and $\left.10 \mathrm{mM} \mathrm{NaF}\right)$ for 15 min on ice. This mixture was loaded onto tandem Superdex 200 10/30 gel filtration columns (Amersham Biosciences, Piscataway, NJ) equilibrated in gel filtration buffer (20 mM HEPES pH 8.0, $1 \mathrm{mM}$ EDTA, $2 \mathrm{mM}$ DTT, $5 \mathrm{mM} \mathrm{MgCl} 2,50 \mathrm{mM} \mathrm{NaCl}, 10 \mu \mathrm{M}$ GDP, $20 \mu \mathrm{M} \mathrm{AlCl}_{3}$, and $10 \mathrm{mM} \mathrm{NaF}$ ). Both $\mathrm{G \alpha}_{\mathrm{i} / 13}$ and $\mathrm{G} \alpha_{\mathrm{i} / 12}$ eluted from the column as apparent monomers. Peak fractions were pooled and concentrated using a Centricon YM-30 (Millipore).

$\mathrm{G} \alpha_{\mathrm{i} / 12}$ was crystallized by mixing $1 \mu \mathrm{l}$ of $22 \mathrm{mg} / \mathrm{ml} \mathrm{G} \alpha_{\mathrm{i} / 12}$ with $1 \mu \mathrm{l}$ well solution containing $100 \mathrm{mM}$ sodium citrate $\mathrm{pH} 6.5,50 \mathrm{mM} \mathrm{NaCl}$, and $14 \%$ PEG 8000, and then suspending the drop over $1 \mathrm{ml}$ of well solution at $4^{\circ} \mathrm{C}$. Paper-thin, diamond shaped crystals appeared within one week. $\mathrm{Ga}_{\mathrm{i} / 13}$ was crystallized similarly, except using $19 \mathrm{mg} / \mathrm{ml} \mathrm{Ga}_{\mathrm{i} / 13}$ and a well solution 
containing $100 \mathrm{mM}$ sodium citrate (pH 4.8), $50 \mathrm{mM} \mathrm{NaCl}$, and 10\% PEG 2000. Tetragonal rod-shaped crystals appeared in 7 to 20 days. Both crystals were stabilized in a harvesting solution containing all the components of both the gel filtration buffer and their respective well solution, and were serially transferred, in 5\% steps at a time, into a final concentration of $20 \%$ glycerol in harvesting solution. Crystals were then flash frozen in liquid nitrogen on nylon loops.

\section{X-ray analysis and structure determination}

Diffraction maxima were measured from crystals maintained at $100 \mathrm{~K}$ at the Advanced Photon Source beam line 17-ID using a Quantum $210 \mathrm{CCD}$ detector. $\mathrm{G} \alpha_{\mathrm{i} / 12}$ crystals exhibited severely anisotropic diffraction with disorder in the maxima that could have been due to warping of the extremely thin crystals. These defects, along with lower resolution diffraction limits, are probably responsible for the relatively high $\mathrm{R}$-factors in the resulting model of $\mathrm{G} \alpha_{\mathrm{i} / 12}$ compared to the $\mathrm{G} \alpha_{\mathrm{i} / 13}$ structure (Table I). Data were reduced using HKL2000 (25). The space group choice and phase problem for $\mathrm{G} \alpha_{\mathrm{i} / 13}$ was solved via molecular replacement with the program PHASER (26) using G $\alpha_{\mathrm{i} 1} \cdot \mathrm{GDP} \cdot \mathrm{AlF}_{4}^{-}{ }^{-}$(PDB code: $1 \mathrm{AGR}$ ) as the search model. The $\mathrm{G} \alpha_{\mathrm{i} / 12}$ structure was determined using the partially refined $\mathrm{G}_{\mathrm{i} / 13}$ structure as the search model. Each model was refined with several rounds of simulated annealing in CNS_SOLVE (27) and then restrained-refinement in REFMAC5 (28). Two-fold non-crystallographic symmetry restraints were used during refinement of $\mathrm{G \alpha}_{\mathrm{i} / 12}$. Model building was performed with $\mathrm{O}$ (29). All reflections were used in the last round of refinement with final combined R-factors of $23.7 \%$ and $21.1 \%$ for the $\mathrm{Ga}_{\mathrm{i} / 12} \cdot \mathrm{GDP} \cdot \mathrm{AlF}_{4}{ }^{-}$and $\mathrm{G} \alpha_{\mathrm{i} / 13} \cdot \mathrm{GDP}$ structures, respectively. Coordinates and structure factors for the $\mathrm{G \alpha}_{\mathrm{i} / 12}$ and $\mathrm{G} \alpha_{\mathrm{i} / 13}$ structures are deposited at the PDB with accession codes 1ZCA and 1ZCB, respectively.

\section{Miscellaneous procedures}

GTP $\gamma \mathrm{S}$ binding to $\mathrm{G} \alpha_{\mathrm{i} / 13}$ or $\mathrm{G} \alpha_{13}$ was measured by filter binding assays as described previously (23). Single-turnover GTP hydrolysis by $\mathrm{G} \alpha_{\mathrm{i} / 13}$ or $\mathrm{G} \alpha_{\mathrm{i} / 12}$ was analyzed in the absence (basal) or presence of $100 \mathrm{nM}$ GST-p115-RH or GST-LARG-RH, as described previously for $\mathrm{G \alpha}_{13}$ or $\mathrm{G} \alpha_{12}$ (16). EE-tagged, full-length $\mathrm{p} 115 \mathrm{RhoGEF}$ and $\mathrm{G} \alpha_{13}$ were purified as described (24). Atomic representations were created with the program PYMOL (30).

\section{Results and Discussion}

\section{Soluble expression of functional $\mathrm{Ga}_{\mathrm{i} / 12}$ or $\mathrm{Ga}_{\mathrm{i} / 13}$ in insect cells}

To increase yields of functional $\mathrm{G} \alpha_{12}$ or $\mathrm{G} \alpha_{13}$, we constructed the $\mathrm{G} \alpha_{\mathrm{i} / 12}$ and $\mathrm{G} \alpha_{\mathrm{i} / 13}$ chimera, in which the N-terminal helices of mouse $\mathrm{G} \alpha_{12}$ or $\mathrm{G} \alpha_{13}$ were swapped with that of rat $\mathrm{G} \alpha_{i 1}$ (Fig. 1A and Figure S1). The $\mathrm{G} \alpha_{\mathrm{i} / 13}$ chimera partitioned almost equally to the soluble and crude membrane fractions of Sf9 cells (data not shown). The soluble $\mathrm{G} \alpha_{\mathrm{i} / 13}$ exhibited activationdependent trypsin protection indicative of a functional $\mathrm{G} \alpha$ subunit (Fig. S2). Similar results were also obtained with $\mathrm{G \alpha}_{\mathrm{i} / 12}$ (data not shown). The yield of $\mathrm{G} \alpha_{\mathrm{i} / 13}$ was about $3.5 \mathrm{mg}$ from 1 liter of Sf9 cell culture after Ni-NTA agarose chromatography (Fig. 1B), representing a vast improvement from previous methods (31). Similarly, the yield of $\mathrm{Ga}_{\mathrm{i} / 12}$ was about $4.0 \mathrm{mg}$ from 1 liter of culture (Fig. 1B). The expression of analogous chimeric proteins in E. coli resulted in large yields of soluble protein, but these proteins could not bind guanine nucleotides (data not shown).

\section{$G \alpha_{i / 12}$ and $G \alpha_{i / 13}$ subunits bind guanine nucleotides and $G \beta Y$}

$\mathrm{G \alpha}_{12 / 13}$ subunits possess biochemical properties that are distinct from those of most other $\mathrm{G} \alpha$ subunits. These include rates of nucleotide exchange $\left(\sim 0.01 \mathrm{~min}^{-1}\right)$ and GTP hydrolysis $\left(\sim 0.2 \mathrm{~min}^{-1}\right)$ that are roughly $3-10$ fold slower than those of $\mathrm{G} \alpha_{\mathrm{s}}$ and $\mathrm{G} \alpha_{\mathrm{i}}$ subfamilies $(20,21$, 
32). The activity of purified $\mathrm{G} \alpha_{\mathrm{i} / 13}$ was evaluated by GTP $\gamma \mathrm{S}$ binding assays. GTP $\gamma \mathrm{S}$ binding to $\mathrm{G} \alpha_{\mathrm{i} / 13}$ was effectively reduced in the presence of $\mathrm{AlF}_{4}{ }^{-}$, which was similar to control samples containing purified $\mathrm{G} \alpha_{\mathrm{i} 1}$ (Fig. S2). Furthermore, purified $\mathrm{G} \alpha_{\mathrm{i} / 13}$ bound $\mathrm{GTP} \gamma \mathrm{S}$ with similar kinetics as wild-type $\mathrm{G} \alpha_{13}$ (Fig. 1C). $\mathrm{G} \alpha_{\mathrm{i} / 12}$ also bound $\mathrm{GTP} \gamma \mathrm{S}$ similarly to wild-type $\mathrm{G} \alpha_{12}$ (data not shown). Because the N-terminal helix of $\mathrm{G} \alpha$ subunits is known to interact with $\mathrm{G} \beta \gamma$ (33-35), we tested whether its substitution affected association of $G \alpha_{i / 12}$ or $G \alpha_{i / 13}$ with $G \beta \gamma$, as measured by the reduced binding of GTP $\gamma \mathrm{S}$ to $\mathrm{G} \alpha$ in the presence of G $\beta \gamma$ (36). Assays performed in the presence of excess G $\beta \gamma$ showed marked inhibition of GTP $\gamma \mathrm{S}$ binding to both chimeric proteins (Fig. 1D), indicating that $\mathrm{G \alpha}_{\mathrm{i} / 12}$ and $\mathrm{G} \alpha_{\mathrm{i} / 13}$ retain the ability to interact with G $\beta \gamma$.

\section{RhoGEFs exhibit GAP activity for $\mathrm{Ga}_{\mathrm{i} / 12}$ or $\mathrm{Ga}_{\mathrm{i} / 13}$}

$\mathrm{G} \alpha_{12}$ and $\mathrm{G} \alpha_{13}$ interact with the RH domain of $\mathrm{p} 115 \mathrm{RhoGEF}$ or LARG in an $\mathrm{AlF}_{4}{ }^{-}$-dependent manner $(15,16)$. As shown in Figure 2, $\mathrm{G \alpha}_{\mathrm{i} / 12}$ and $\mathrm{G \alpha} \alpha_{\mathrm{i} / 13}$ also interacted with RH domaincontaining fragments of $\mathrm{p} 115 \mathrm{RhoGEF}$ or LARG in an $\mathrm{AlF}_{4}{ }^{-}$-dependent manner, as assessed by GST pull-down assays. We also could isolate high affinity complexes of each chimeric G protein with the RH domain of LARG by size exclusion chromatography (data not shown). We next examined whether these same p115RhoGEF or LARG fragments exhibit GAP activity for the chimera. Both fragments accelerated the GTPase activity of $\mathrm{G} \alpha_{\mathrm{i} / 12}$ and $\mathrm{G} \alpha_{\mathrm{i} / 13}$ in singleturnover GTPase assays (Fig. 3A), with a faster response in $\mathrm{G \alpha}_{\mathrm{i} / 13}$ than in $\mathrm{G} \alpha_{\mathrm{i} / 12}$, as previously observed for their wild-type counterparts $(15,16)$.

\section{Regulation of RhoGEF activity by $\mathrm{Ga}_{\mathrm{i} / 13}$ or $\mathrm{Ga}_{\mathrm{i} / \mathbf{1 2}}$}

$\mathrm{G} \alpha_{13}$, but not $\mathrm{G} \alpha_{12}$, directly stimulates $\mathrm{p} 115 \mathrm{RhoGEF}-$ mediated nucleotide exchange on RhoA (13). To assess whether our chimera could similarly regulate RhoGEF activity, we measured GTP $\gamma \mathrm{S}$ binding to RhoA in the presence of $\mathrm{p} 115 \mathrm{RhoGEF}$ and $\mathrm{AlF}_{4}{ }^{-}$-activated $\mathrm{Go}_{\mathrm{i} / 12}$ or $\mathrm{G} \alpha_{\mathrm{i} / 13}$. As shown in Figure 3B, $\mathrm{G \alpha}_{\mathrm{i} / 13}$, but not $\mathrm{G} \alpha_{\mathrm{i} / 12}$, could stimulate $\mathrm{p} 115 \mathrm{RhoGEF}$. The doseresponse curve of $\mathrm{G \alpha}_{\mathrm{i} / 13}$ for $\mathrm{p} 115 \mathrm{RhoGEF}$ activation is similar to that of wild-type $\mathrm{G} \alpha_{13}$ (Fig. 3C). Thus, $\mathrm{G} \alpha_{\mathrm{i} / 12}$ and $\mathrm{G} \alpha_{\mathrm{i} / 13}$ regulate effector molecules with specificity similar to their wildtype counterparts.

In summary, $\mathrm{G} \alpha_{\mathrm{i} / 12}$ and $\mathrm{G} \alpha_{\mathrm{i} / 13}$ chimeras retain the specific biochemical properties of their wildtype counterpart subunits. Although the $\mathrm{N}$-terminal helices of $\mathrm{G} \alpha$ subunits are involved in binding $G \beta \gamma$ subunits, regulation of effector molecules, and specific interaction with receptors $(33,37,38)$, substitution of the N-terminal helix of either $\mathrm{G} \alpha_{12}$ or $\mathrm{G} \alpha_{13}$ with that of $\mathrm{G} \alpha_{i 1}$ did not affect its interaction with $\mathrm{G} \beta \gamma$ or RhoGEFs insofar as our assays could detect. Thus, the native $\mathrm{N}$-terminal helix of $\mathrm{G \alpha}_{12 / 13}$, while important for receptor selectivity (38), is not essential for the regulation of RhoGEFs.

\section{Structure determination of $\mathrm{Ga}_{\mathrm{i} / 12}$ and $\mathrm{Ga}_{\mathrm{i} / 13}$}

Both $\mathrm{G} \alpha_{\mathrm{i} / 12}$ and $\mathrm{G} \alpha_{\mathrm{i} / 13}$ were activated with $\mathrm{AlF}_{4}{ }^{-}$prior to crystallization, and their structures were determined by molecular replacement (Table I). As is typical for structures of monomeric $\mathrm{G} \alpha$ subunits, the $\mathrm{N}$-terminal helices and extreme $\mathrm{C}$-termini are disordered. The structure of $\mathrm{G \alpha}_{\mathrm{i} / 12} \cdot \mathrm{GDP} \cdot \mathrm{AlF}_{4}{ }^{-}$spans residues 54 to 371 , and therefore contains only wild-type residues (Fig. 4A). G $\alpha_{\mathrm{i} / 13}$ was resolved in a GDP-bound state that most closely resembles the deactivated structures of $\mathrm{G} \alpha_{i}$ and $\mathrm{G} \alpha_{\mathrm{t}}$ (Fig. 4B, Fig. 5B). In its structure, only one residue derived from $\mathrm{Ga}_{\mathrm{i}}$ at the chimeric N terminus is observed, and a portion of switch II (residues 226 to 232) and two residues in the $\alpha 4-\beta 6$ loop (residues 339 to 340 ) are additionally disordered (Fig. 4B). It is somewhat surprising that the $\mathrm{G} \alpha_{\mathrm{i} / 13}$ protein crystallized in a deactivated state because both $\mathrm{G} \alpha_{\mathrm{i} / 12}$ and $\mathrm{G} \alpha_{\mathrm{i} / 13}$ were activated using the same protocol, formed stable complexes with $\mathrm{RH}$ domains (Fig. 2) and were resistant to trypsin digestion (Fig. S2). However, $\mathrm{AlF}_{4}{ }^{-}$binding is reversible, and different crystallization conditions likely lead to different proportions of 
proteins in activated and deactivated states. The relatively low $\mathrm{pH}$ used for the crystallization of $\mathrm{G}_{\mathrm{i} / 13}$ ( $\mathrm{pH} 4.8$ ), for example, could destabilize the activated, $\mathrm{AlF}_{4}{ }^{-}$-bound state and allow the deactivated protein to crystallize (39). Previously reported $\mathrm{G} \alpha \cdot \mathrm{AlF}_{4}{ }^{-}$complexes were crystallized at $\mathrm{pH}$ values 5.5 or higher.

\section{Comparison of the $\mathrm{Ga}_{\mathrm{i} / \mathbf{1 2}}$ and $\mathrm{G} \alpha_{\mathrm{i} / 13}$ structures}

Like other $\mathrm{G} \alpha$ subunits, $\mathrm{G} \alpha_{\mathrm{i} / 12}$ and $\mathrm{G} \alpha_{\mathrm{i} / 13}$ are composed of a nucleotide-binding domain homologous to that of Ras, into which an $\alpha$-helical domain is inserted (Fig. 4). The most dramatic difference between $\mathrm{Go}_{\mathrm{i} / 12} \cdot \mathrm{GDP} \cdot \mathrm{AlF}_{4}{ }^{-}$and $\mathrm{G \alpha}_{\mathrm{i} / 13} \cdot \mathrm{GDP}$ is an $\sim 8.5^{\circ}$ rotation of the $\alpha$ helical domain away from the Ras-like domain in $\mathrm{Ga}_{\mathrm{i} / 13}$. GDP (Fig. 4C). Among previous $\mathrm{G} \alpha_{\mathrm{i}}$ and $\mathrm{G} \alpha_{\mathrm{t}}$ crystal structures, the Ras-like and $\alpha$-helical domains differ in relative orientation only by $\sim 2.5^{\circ}$ between their activated and deactivated states. Thus, the $\mathrm{G} \alpha_{\mathrm{i} / 13}$ structure is unusually "open" in conformation. This is most likely due to its activation state and not to differences in primary sequence between $\mathrm{G \alpha}_{12}$ and $\mathrm{G} \alpha_{13}$ (see below discussion).

In addition to the three switch regions, which are well known to exhibit activation-dependent conformational changes, the Ras-like domains of $\mathrm{G} \alpha_{\mathrm{i} / 12}$ and $\mathrm{G} \alpha_{\mathrm{i} / 13}$ exhibit differences in the $\alpha 4-\beta 6$ loop, which is disordered and one residue longer in $\mathrm{G} \alpha_{\mathrm{i} / 13}$. In other $\mathrm{G} \alpha$ subunits, this loop, along with the $\mathrm{C}$-terminus, is thought to contribute to receptor specificity (reviewed in (40)). More subtle differences are also evident in the backbone of the $\alpha 3-\beta 5$ loop, a region known to interact with effector proteins in $\mathrm{G} \alpha_{\mathrm{s}}$ and $\mathrm{G} \alpha_{\mathrm{t}}(4,41)$, although this could be affected by an effector-like crystal contact in the $\mathrm{G} \alpha_{\mathrm{i} / 12}$ crystal lattice (Fig. S3). Excluding these regions, the Ras-like domains of $\mathrm{G} \alpha_{\mathrm{i} / 12}$ and $\mathrm{G} \alpha_{\mathrm{i} / 13}$ are quite similar, as might be expected by their $70 \%$ sequence identity. They superimpose with a root mean squared deviation (RMSD) of $0.75 \AA$ for 175 equivalent $\mathrm{C}^{\alpha}$ atoms (Fig. 4C).

The $\alpha$-helical domains of $\mathrm{G \alpha}_{\mathrm{i} / 12}$ and $\mathrm{G \alpha}_{\mathrm{i} / 13}$ exhibit more profound differences. In $\mathrm{G} \alpha_{\mathrm{i} / 13}$, the $\mathrm{N}$-terminus of $\alpha \mathrm{A}$ is kinked due to the presence of Pro86 (Asp93 in $\mathrm{G} \alpha_{12}$ ), and the $\alpha \mathrm{B}-\alpha \mathrm{C}$ loop is four residues longer and harbors an additional helix $(\alpha \mathrm{B} 1$; Fig. 4B). Omitting these regions, the domains superimpose with an RMSD of $0.7 \AA$ for 101 equivalent $C^{\alpha}$ atoms. Intriguingly, the $\alpha \mathrm{D}-\alpha \mathrm{E} 1$ loop of $\mathrm{G} \alpha_{\mathrm{i} / 13}$ (residues 171 to 173 , immediately adjacent to the nucleotide binding site) adopts a strikingly different conformation from the analogous loops in the activated $\mathrm{G} \alpha_{\mathrm{i} / 12}$ and $\mathrm{G} \alpha_{13 / \mathrm{i}^{-}}$structures, even though these loops have identical primary structure (Fig. $5 \mathrm{~A}, 5 \mathrm{~B})$. Therefore, the $\alpha \mathrm{D}-\alpha \mathrm{E} 1$ loop also appears to exhibit a novel activation-dependent conformational change.

\section{Comparison of $\mathrm{Ga}_{12 / 13}$ subunits with other $\mathrm{Ga}$ subfamilies}

In line with their sequence identities ( $43 \%$ and 39\%, respectively), the Ras-like domains of $\mathrm{G} \alpha_{12 / 13}$ are more similar to $\mathrm{G} \alpha_{\mathrm{i}}$ than $\mathrm{G} \alpha_{\mathrm{s}}$, with RMSDs of superposition of $1.1 \AA$ and $2.2 \AA$ for 184 and 170 equivalent $C^{\alpha}$ atoms, respectively. Regions exhibiting obvious structural differences among the Ras-like domains of $\mathrm{G} \alpha_{12 / 13}, \mathrm{G} \alpha_{\mathrm{i}}$, and $\mathrm{G} \alpha_{\mathrm{s}}$ are the $\alpha 4-\beta 6$ loop, which projects further away from the Ras-like domain in $\mathrm{G}_{12 / 13}$ subunits, and the $\beta 5-\alpha 4$ loop (Fig. 4C). The cleft formed between the $\alpha 2$ (switch II) and $\alpha 3$ helices and their C-terminal loops is increasingly recognized as the effector binding site of $\mathrm{G} \alpha(17,41,42)$. In $\mathrm{G}_{12 / 13}$ subunits, the $\alpha 3-\beta 5$ loop is most similar to that of $\mathrm{G} \alpha_{\mathrm{t}}$. Differences between the $\alpha$-helical domains of $\mathrm{G}_{12 / 13}$ and $\mathrm{G} \alpha$ subunits from other subfamilies have been described previously (17).

\section{Activation-Dependent Conformational changes in $\mathrm{Ga}_{12 / 13}$ subunits}

Comparison of the structures of $\mathrm{G} \alpha_{\mathrm{i} / 12} \cdot \mathrm{GDP} \cdot \mathrm{AlF}_{4}{ }^{-}, \mathrm{G} \alpha_{\mathrm{i} / 13} \cdot \mathrm{GDP}$ and $\mathrm{G} \alpha_{13 / \mathrm{i}^{-}}-5 \cdot \mathrm{GDP} \cdot \mathrm{AlF}_{4}{ }^{-}$ reveals conformational changes that appear to be linked to GTP hydrolysis in $\mathrm{G}_{12 / 13}$ subunits (Fig. 4 and Movie S1). This important deactivation mechanism has previously only been described for the $\mathrm{G} \alpha_{\mathrm{i}}$ subfamily of $\mathrm{G}$ proteins. In the $\mathrm{G} \alpha_{\mathrm{i} / 12} \cdot \mathrm{GDP} \cdot \mathrm{AlF}_{4}{ }^{-}$structure, the three 
switch regions and the $\alpha$-helical domain adopt a conformation similar to those of the activated structures of $\mathrm{G} \alpha_{\mathrm{i}}, \mathrm{G} \alpha_{\mathrm{t}}$ and $\mathrm{G} \alpha_{\mathrm{s}}$. In $\mathrm{G} \alpha_{\mathrm{i} / 13}$. GDP, switch I retains this activated conformation except for residues 206 to 210 at the $\mathrm{C}$ terminus of the switch, which shift by as much as $2 \AA$ towards the $\alpha$-helical domain (Fig. 4C), a conformation previously observed in several GDPbound structures of $\mathrm{G \alpha}_{\mathrm{i}}(34,43)$. Less of switch II is disordered in the $\mathrm{G \alpha}_{\mathrm{i} / 13}$. GDP structure than in $\mathrm{G} \alpha_{\mathrm{i} 1} \cdot \mathrm{GDP}$, and switch III rotates $13^{\circ}$ away from the active site to a position nearly identical to that observed in the $\mathrm{G}_{\mathrm{t}} \cdot \mathrm{GDP}$ complex (44).

As described above, the $\alpha$-helical domain of $\mathrm{G} \alpha_{\mathrm{i} / 13}$ also appears to undergo activationdependent conformational changes (Fig. 4C, 5B) by rotating away from the Ras-like domain and by alteration of the $\alpha \mathrm{D}-\alpha \mathrm{E} 1$ loop (residues 171 to $173 \mathrm{in} \mathrm{G}_{\mathrm{i} / 13}$ ). In other subfamilies, $\mathrm{G}_{13}$-Glu172 is substituted by aspartate, which interacts with an invariant lysine in the Raslike domain $\left(\mathrm{G \alpha}_{13}\right.$-Lys292) and packs against the purine ring and ribose sugar of GDP. The unusually open conformation of $\mathrm{G} \alpha_{\mathrm{i} / 13}$. GDP allows the longer $\mathrm{G}_{13}$-Glu172 side chain to form an analogous salt bridge (Fig. 5A), although in electron density maps this side chain appears less ordered than its neighboring residues. Contrarily, in activated structures of $\mathrm{G} \alpha_{12}$ and $\mathrm{G} \alpha_{13 / i}-5$, the $\alpha \mathrm{D}-\alpha \mathrm{E} 1$ loop is puckered, apparently to avoid steric collisions, and $\mathrm{G} \alpha_{13}$-Glu172 makes relatively few contacts with the bound nucleotide (Fig. 5). Thus, the $\alpha \mathrm{D}-\alpha \mathrm{E} 1$ loop thus acts like an activation-dependent "spring" that appears to push the $\alpha$-helical domain away from the Ras-like domain in the $\mathrm{G} \alpha_{\mathrm{i} / 13}$. GDP structure. This transition may be facilitated by the loss of contacts between the $\alpha$-helical domain and switch III upon GTP hydrolysis.

To better understand whether these conformational differences are coupled to GTP hydrolysis and not to differences in primary structure, we need atomic structures of the activated and deactivated forms of both $\mathrm{G} \alpha_{\mathrm{i} / 12}$ and $\mathrm{G} \alpha_{\mathrm{i} / 13}$. Currently, $\mathrm{G} \alpha_{\mathrm{i} / 12}$. GDP has not been crystallized, and we only have the $\mathrm{G} \alpha_{13 / i}-5$ chimera to represent the activated structure of $\mathrm{G} \alpha_{13}$. Despite this, the $70 \%$ sequence identity of $\mathrm{G \alpha}_{12}$ and $\mathrm{G \alpha}_{13}$ and the $100 \%$ identity of their $\alpha \mathrm{D}-\alpha \mathrm{E} 1$ loops suggest that they undergo similar conformational changes upon deactivation. Indeed, the activated structures of $\mathrm{G} \alpha_{\mathrm{i} / 12}$ and the $\mathrm{G} \alpha_{13 / \mathrm{i}}-5$ chimera are remarkably similar despite their even higher sequence disparity. Furthermore, in the $\mathrm{G} \alpha_{\mathrm{i} / 13}$. GDP structure, the $\alpha \mathrm{D}-\alpha \mathrm{E} 1$ loop adopts the same conformation as those of activated and deactivated structures of $\mathrm{G} \alpha_{\mathrm{i}}, \mathrm{G} \alpha_{\mathrm{t}}$ and $\mathrm{G} \alpha_{s}$, suggesting that this is the energetically preferred state, which can only be attained in $\mathrm{G \alpha}_{12 / 13}$ subunits after GTP hydrolysis and outward rotation of the helical domain. However, as in any crystal structure, we cannot totally exclude the possibility that the unusually open conformation of the $\mathrm{G \alpha}_{\mathrm{i} / 13}$. GDP structure was also influenced by lattice contacts or crystallization conditions.

If the open conformation of the $\mathrm{G \alpha}_{\mathrm{i} / 13}$. GDP structure and the structural transition of the $\alpha \mathrm{D}$ $\alpha \mathrm{E} 1$ loop indeed represent activation-dependent conformational changes in $\mathrm{G} \alpha_{12 / 13}$ subunits, what might their physiological significance be? Because the Ras-like and $\alpha$-helical domains of $\mathrm{G \alpha}_{13}$ are both known to interact with the N-terminal fragment p115RhoGEF (17), the open conformation of deactivated $\mathrm{Ga}_{\mathrm{i} / 13}$. GDP could help discourage interactions with $\mathrm{p} 115 \mathrm{RhoGEF}$ or LARG upon GTP hydrolysis. Another consequence of the open conformation of $\mathrm{G} \alpha_{\mathrm{i} / 13} \cdot \mathrm{GDP}$ is that the nucleotide appears less solvent accessible in deactivated $\mathrm{G} \alpha_{\mathrm{i} / 13}$ than in activated $\mathrm{G} \alpha_{12 / 13}$ subunits $\left(\sim 14.5 \AA^{2}\right.$ of accessible surface area in the $\mathrm{G \alpha}_{\mathrm{i} / 12} \cdot \mathrm{GDP} \cdot \mathrm{AlF}_{4}{ }^{-}$and $\mathrm{G}_{13 / \mathrm{i}}-5 \cdot \mathrm{GDP} \cdot \mathrm{AlF}_{4}^{-}$complexes, and $6.9 \AA^{2}$ in the $\mathrm{G} \alpha_{\mathrm{i} / 13} \cdot \mathrm{GDP}$ complex). The opposite is true in $\mathrm{G}_{\mathrm{i}}$ subunits (e.g. $18.8 \AA^{2}$ in the structure of $\mathrm{G} \alpha_{\mathrm{i}} \cdot \mathrm{GDP}$, and $3.5 \AA^{2}$ in $\mathrm{G}_{\mathrm{i}} \cdot \mathrm{GDP} \cdot \mathrm{AlF}_{4}^{-}$). These differences in the substrate binding site could influence rates of nucleotide exchange and/or hydrolysis, and thus the duration of signals in response to the activation of $G \alpha_{12 / 13}$-coupled receptors. 


\section{Structural insights into the interactions of $\mathrm{Ga}_{12}$ and $\mathrm{G \alpha _{13 }}$ with effectors}

The best-characterized $\mathrm{G} \alpha_{12 / 13}$ effector is the N-terminal fragment of p115RhoGEF, which includes its RH domain (17). Because the $\mathrm{G} \alpha_{13 / \mathrm{i}^{-}}-\mathrm{p}$-p115RhoGEF structure determination employed a $\mathrm{G} \alpha$ subunit with a chimeric effector-binding site, we modeled the p115RhoGEF RH domain complex with our essentially wild-type $\mathrm{G} \alpha_{\mathrm{i} / 13}$ and $\mathrm{Go}_{\mathrm{i} / 12}$ structures. The resulting model reveals that the chimeric residues in the $\mathrm{G} \alpha_{13 / i}-5$-p $115 \mathrm{RhoGEF}$ interface either do not make significant contributions or are conservatively substituted in $\mathrm{G \alpha}_{\mathrm{i} / 13}$ and $\mathrm{Ga}_{\mathrm{i} / 12}$. In line with our observation that the RH domains of $\mathrm{p} 115 \mathrm{RhoGEF}$ and LARG bind $\mathrm{G \alpha} \mathrm{\alpha}_{\mathrm{i} / 12}$ and $\mathrm{G} \alpha_{\mathrm{i} / 13}$ equally well (Fig. 2), the structures of $\mathrm{G} \alpha_{\mathrm{i} / 12}$ and $\mathrm{G} \alpha_{\mathrm{i} / 13}$ have no significant amino acid differences among the residues that contribute to their respective $\mathrm{RH}$ domain binding sites. However, $\mathrm{G} \alpha_{12}$ and $\mathrm{G} \alpha_{13}$ subunits do exhibit differences in their GAP response to p115RhoGEF and LARG. The region immediately N-terminal to the RH domain of p115RhoGEF is responsible for its GAP activity and binds in the cleft formed between the Ras-like and $\alpha$-helical domains $(17,19)$, where it contacts $\alpha \mathrm{A}$ and the $\alpha \mathrm{B}-\alpha \mathrm{C}$ loop. While the interacting residues within $\alpha \mathrm{A}$ are conserved in $\mathrm{G} \alpha_{12}$ and $\mathrm{G} \alpha_{13}$, their $\alpha \mathrm{B}-\alpha \mathrm{C}$ loops have dramatically different structure (Fig. 4). Diminished or detrimental interactions between the shorter $\alpha \mathrm{B}-\alpha \mathrm{C}$ loop of $\mathrm{G} \alpha_{\mathrm{i} / 12}$ and $\mathrm{p} 115 \mathrm{RhoGEF}$ could therefore account for the higher GAP response of $\mathrm{Ga}_{\mathrm{i} / 13}$ with respect to $\mathrm{G} \alpha_{\mathrm{i} / 12}$.

Another relatively-well characterized effector target of activated $\mathrm{G} \alpha_{12 / 13}$ subunits is cadherin (10). Recently, it was shown that mutation of residues 244 to 249 within $\beta 4$ of $G \alpha_{12}$ lead to uncoupling of $\mathrm{G} \alpha_{12}$ from p115RhoGEF and LARG, but not E-cadherin (45). Based on the crystal structure of $G \alpha_{i / 12}$, this substitution is expected to disrupt the effector-binding site of the $\mathrm{G}$ protein, in accordance with the loss of p115RhoGEF and LARG binding. Cadherin either binds elsewhere on $\mathrm{G} \alpha_{\mathrm{i} / 12}$, or is less reliant on a properly structured effector-binding pocket.

\section{Conclusions}

Elucidation of the molecular mechanisms by which $\mathrm{G} \alpha$ subunits regulate their own activity as well as the activity of their effector target is required not only to understand the regulation of many cellular processes, but also to develop drugs designed to modulate such processes.

$\mathrm{G} \alpha_{12}$ and $\mathrm{G} \alpha_{13}$ have similar biochemical properties $(20,21)$, but distinct functional roles in cell signaling, such that $\mathrm{G} \alpha_{13}$ knockout mice die around embryonic day E10 due to a vascular system formation defect (46), whereas $\mathrm{G} \alpha_{12}$ knockout mice are viable and without any obvious phenotype (47). In this study, we demonstrate a simple and efficient method to produce fully functional, soluble forms of $\mathrm{G \alpha}_{12}$ and $\mathrm{G} \alpha_{13}$ that enabled us to determine their crystal structures. These structures reveal molecular differences not only between these two subunits, but also with those of other $\mathrm{G} \alpha$ subunits. By determining the activated structure of $G \alpha_{12}$ and the deactivated structure of $\mathrm{G} \alpha_{13}$, we fortuitously observed novel conformational changes that are likely coupled to GTP hydrolysis. If true, then it can no longer be assumed that the transition upon deactivation will necessarily be the same in all $\mathrm{G} \alpha$ subfamilies. In the future, these chimeric subunits can be used in biochemical and crystallographic analyses to decipher their differential ability to regulate the growing number of effectors that interact with $\mathrm{G} \alpha_{12 / 13}$ subunits (12). Remarkably, the chimeric approach we used to generate soluble $\mathrm{G} \alpha_{12 / 13}$ subunits in this paper can be applied successfully to other, formerly intractable $\mathrm{G} \alpha$ subunits, even from other subfamilies, as evidenced by our successful structural studies of the analogous $G \alpha_{\mathrm{i} / \mathrm{q}}$ chimera in complex with GRK2 and G $\beta \gamma(48)$.

\section{Supplementary Material}

Refer to Web version on PubMed Central for supplementary material. 


\section{Abbreviations}

$\beta \mathrm{ME}, \beta$-mercaptoethanol

DTT, dithiothreitol

EDTA, ethylenediaminetetraacetic acid

$\mathrm{G}$ protein, guanine nucleotide binding protein

$\mathrm{G} \alpha$, heterotrimeric $\mathrm{G}$ protein $\alpha$ subunit

$\mathrm{G} \beta \gamma$, heterotrimeric $\mathrm{G}$ protein $\beta$ and $\gamma$ subunits

GPCR, G protein-coupled receptor

GDP, guanosine-5' -diphosphate

GST, glutathione- $S$-transferase

GTP, guanosine-5'-triphosphate

HEPES, 4-(2-hydroxyethyl)-1-piperazine ethanesulfonic acid

LARG, leukemia-associated RhoGEF

p115RhoGEF, p115 Rho guanine nucleotide exchange factor

RGS, regulator of $G$ protein signaling

RH, RGS homology

SDS, sodium dodecyl sulfate

\section{Acknowledgments}

We would like to thank Yi Li and Beth Dulin for technical assistance. Diffraction data were collected at beam line 17ID of the Industrial Macromolecular Crystallography Association Collaborative Access Team (IMCA-CAT) at the Advanced Photon Source (Argonne, IL). These facilities are supported by the companies of the Industrial Macromolecular Crystallography Association through a contract with Illinois Institute of Technology (IIT), executed through the IIT Center for Synchrotron Radiation Research and Instrumentation. Use of the Advanced Photon Source was supported by the U. S. Department of Energy, Basic Energy Sciences, Office of Science, under Contract No. W-31-109-Eng-38.

\section{References}

1. Neves SR, Ram PT, Iyengar R. G protein pathways. Science 2002;296:1636-1639. [PubMed: 12040175]

2. Hollinger S, Hepler JR. Cellular regulation of RGS proteins: modulators and integrators of G protein signaling. Pharmacol Rev 2002;54:527-559. [PubMed: 12223533]

3. Berman DM, Kozasa T, Gilman AG. The GTPase-activating protein RGS4 stabilizes the transition state for nucleotide hydrolysis. J Biol Chem 1996;271:27209-27212. [PubMed: 8910288]

4. Tesmer JJG, Berman DM, Gilman AG, Sprang SR. Structure of RGS4 bound to $\mathrm{AlF}_{4}{ }^{-}$-activated $\mathrm{G}_{\mathrm{i \alpha 1} 1}$ : stabilization of the transition state for GTP hydrolysis. Cell 1997;89:251-261. [PubMed: 9108480]

5. Hepler JR, Gilman AG. G proteins. Trends Biochem Sci 1992;17:383-387. [PubMed: 1455506]

6. Dhanasekaran N, Dermott JM. Signaling by the $\mathrm{G}_{12}$ class of G proteins. Cell Signal 1996;8:235-245. [PubMed: 8842523]

7. Whitehead IP, Zohn IE, Der CJ. Rho GTPase-dependent transformation by G protein-coupled receptors. Oncogene 2001;20:1547-1555. [PubMed: 11313901]

8. Sah VP, Seasholtz TM, Sagi SA, Brown JH. The role of Rho in G protein-coupled receptor signal transduction. Annu Rev Pharmacol Toxicol 2000;40:459-489. [PubMed: 10836144]

9. Sahai E, Marshall CJ. RHO-GTPases and cancer. Nat Rev Cancer 2002;2:133-142. [PubMed: 12635176]

10. Meigs TE, Fields TA, McKee DD, Casey PJ. Interaction of $\mathrm{G} \alpha_{12}$ and $\mathrm{G} \alpha_{13}$ with the cytoplasmic domain of cadherin provides a mechanism for $\beta$-catenin release. Proc Natl Acad Sci U S A 2001;98:519-524. [PubMed: 11136230]

11. Yamaguchi Y, Katoh H, Mori K, Negishi M. G $\alpha_{12}$ and $\mathrm{G} \alpha_{13}$ interact with Ser/Thr protein phosphatase type 5 and stimulate its phosphatase activity. Curr Biol 2002;12:1353-1358. [PubMed: 12176367] 
12. Kurose $\mathrm{H} . \mathrm{G} \alpha_{12}$ and $\mathrm{G} \alpha_{13}$ as key regulatory mediator in signal transduction. Life Sci 2003;74:155161. [PubMed: 14607242]

13. Hart MJ, Jiang X, Kozasa T, Roscoe W, Singer WD, Gilman AG, Sternweis PC, Bollag G. Direct stimulation of the guanine nucleotide exchange activity of p115 RhoGEF by $\mathrm{G} \alpha_{13}$. Science 1998;280:2112-2114. [PubMed: 9641916]

14. Fukuhara S, Murga C, Zohar M, Igishi T, Gutkind JS. A novel PDZ domain containing guanine nucleotide exchange factor links heterotrimeric G proteins to Rho. J Biol Chem 1999;274:58685879. [PubMed: 10026210]

15. Suzuki N, Nakamura S, Mano H, Kozasa T. G $\alpha_{12}$ activates Rho GTPase through tyrosinephosphorylated leukemia-associated RhoGEF. Proc Natl Acad Sci U S A 2003;100:733-738. [PubMed: 12515866]

16. Kozasa T, Jiang X, Hart MJ, Sternweis PM, Singer WD, Gilman AG, Bollag G, Sternweis PC. p115 RhoGEF, a GTPase activating protein for $\mathrm{G}_{12}$ and $\mathrm{G} \alpha_{13}$. Science 1998;280:2109-2111. [PubMed: 9641915]

17. Chen Z, Singer WD, Sternweis PC, Sprang SR. Structure of the p115RhoGEF rgRGS domain-G $\alpha_{13 /}$ i1 chimera complex suggests convergent evolution of a GTPase activator. Nat Struct Mol Biol 2005;12:191-197. [PubMed: 15665872]

18. Chen Z, Singer WD, Wells CD, Sprang SR, Sternweis PC. Mapping the G $\alpha_{13}$ binding interface of the rgRGS domain of p115RhoGEF. J Biol Chem 2003;278:9912-9919. [PubMed: 12525488]

19. Wells CD, Liu MY, Jackson M, Gutowski S, Sternweis PM, Rothstein JD, Kozasa T, Sternweis PC. Mechanisms for reversible regulation between $\mathrm{G}_{13}$ and Rho exchange factors. J Biol Chem 2002;277:1174-1181. [PubMed: 11698392]

20. Kozasa T, Gilman A. Purification of recombinant G proteins from Sf9 cells by hexahistidine tagging of associated subunits. Characterization of $\alpha_{12}$ and inhibition of adenylyl cyclase by $\alpha_{z}$. J Biol Chem 1995;270:1734-1741. [PubMed: 7829508]

21. Singer WD, Miller RT, Sternweis PC. Purification and characterization of the $\alpha$ subunit of $\mathrm{G}_{13}$. J Biol Chem 1994;269:19796-19802. [PubMed: 8051060]

22. Yasukawa T, Kanei-Ishii C, Maekawa T, Fujimoto J, Yamamoto T, Ishii S. Increase of solubility of foreign proteins in Escherichia coli by coproduction of the bacterial thioredoxin. J Biol Chem 1995;270:25328-25331. [PubMed: 7592692]

23. Nakamura S, Kreutz B, Tanabe S, Suzuki N, Kozasa T. Critical role of lysine 204 in switch I region of $\mathrm{G} \alpha_{13}$ for regulation of $\mathrm{p} 115 \mathrm{RhoGEF}$ and leukemia-associated RhoGEF. Mol Pharmacol 2004;66:1029-1034. [PubMed: 15258251]

24. Tanabe S, Kreutz B, Suzuki N, Kozasa T. Regulation of RGS-RhoGEFs by $\mathrm{G} \alpha_{12}$ and $\mathrm{G} \alpha_{13}$ proteins. Methods Enzymol 2004;390:285-294. [PubMed: 15488184]

25. Otwinoski Z, Minor W. Processing of X-ray diffraction data collected in oscillation mode. Methods Enzymol 1997;276:307-326.

26. Storoni LC, McCoy AJ, Read RJ. Likelihood-enhanced fast rotation functions. Acta Crystallogr D Biol Crystallogr 2004;60:432-438. [PubMed: 14993666]

27. Brünger AT, Adams PD, Clore GM, DeLano WL, Gros P, Grosse-Kunstleve RW, Jiang JS, Kuszewski J, Nilges M, Pannu NS, Read RJ, Rice LM, Simonson T, Warren GL. Crystallography \& NMR system: A new software suite for macromolecular structure determination. Acta Crystallogr D Biol Crystallogr 1998;54:905-921. [PubMed: 9757107]

28. Winn MD. An overview of the CCP4 project in protein crystallography: an example of a collaborative project. J Synchrotron Radiat 2003;10:23-25. [PubMed: 12511787]

29. Jones TA, Zou JY, Cowan SW, Kjeldgaard M. Improved methods for the building of protein models in electron density maps and the location of errors in these models. Acta Crystallogr 1991;A47:110119.

30. DeLano, W. The PyMOL Molecular Graphics System. San Carlos, CA, USA: DeLano Scientific; 2002.

31. Kozasa T. Purification of G protein subunits from Sf9 insect cells using hexahistidine-tagged $\alpha$ and $\beta \gamma$ subunits. Methods Mol Biol 2004;237:21-38. [PubMed: 14501036]

32. Linder M, Ewald D, Miller R, Gilman A. Purification and characterization of $\mathrm{G}_{\mathrm{o} \alpha}$ and three types of $\mathrm{G}_{i \alpha}$ after expression in Escherichia coli. J Biol Chem 1990;265:8243-8251. [PubMed: 2159473] 
33. Neer EJ, Pulsifer L, Wolf LG. The amino terminus of G protein $\alpha$ subunits is required for interaction with $\beta \gamma$. J Biol Chem 1988;263:8996-70. [PubMed: 3132454]

34. Wall MA, Coleman DE, Lee E, Iniguez-Lluhi JA, Posner BA, Gilman AG, Sprang SR. The structure of the $G$ protein heterotrimer $G_{i \alpha 1} \beta_{1} \gamma_{2}$. Cell 1995;83:1047-1058. [PubMed: 8521505]

35. Lambright DG, Sondek J, Bohm A, Skiba NP, Hamm HE, Sigler PB. The 2.0 A crystal structure of a heterotrimeric G protein. Nature 1996;379:311-319. [PubMed: 8552184]

36. Brandt DR, Ross EM. GTPase activity of the stimulatory GTP-binding regulatory protein of adenylate cyclase, $\mathrm{G}_{\mathrm{s}}$. Accumulation and turnover of enzyme-nucleotide intermediates. J Biol Chem 1985;260:266-272. [PubMed: 2981206]

37. Hepler JR, Biddlecome GH, Kleuss C, Camp LA, Hofmann SL, Ross EM, Gilman AG. Functional importance of the amino terminus of $\mathrm{G}_{\mathrm{q} \alpha}$. J Biol Chem 1996;271:496-504. [PubMed: 8550609]

38. Yamaguchi Y, Katoh H, Negishi M. N-terminal short sequences of $\alpha$ subunits of the $\mathrm{G}_{12}$ family determine selective coupling to receptors. J Biol Chem 2003;278:14936-14939. [PubMed: 12594220]

39. Schlichting I, Reinstein J.pH influences fluoride coordination number of the AlFx phosphoryl transfer transition state analog. Nat Struct Biol 1999;6:721-723. [PubMed: 10426946]

40. Cabrera-Vera TM, Vanhauwe J, Thomas TO, Medkova M, Preininger A, Mazzoni MR, Hamm HE. Insights into G protein structure, function, and regulation. Endocr Rev 2003;24:765-781. [PubMed: 14671004]

41. Slep KC, Kercher MA, He W, Cowan CW, Wensel TG, Sigler PB. Structural determinants for regulation of phosphodiesterase by a G protein at $2.0 \AA$. Nature 2001;409:1071-1077. [PubMed: 11234020]

42. Tesmer J, Sunahara R, Gilman A, Sprang S. Crystal structure of the catalytic domains of adenylyl cyclase in a complex with $\mathrm{G}_{\mathrm{s} \alpha} \cdot \mathrm{GTP} \gamma \mathrm{S}$. Science 1997;278:1907-1916. [PubMed: 9417641]

43. Kimple RJ, Kimple ME, Betts L, Sondek J, Siderovski DP. Structural determinants for GoLocoinduced inhibition of nucleotide release by Ga subunits. Nature 2002;416:878-881. [PubMed: 11976690]

44. Lambright DG, Noel JP, Hamm HE, Sigler PB. Structural determinants for activation of the $\alpha$-subunit of a heterotrimeric G protein. Nature 1994;369:621-628. [PubMed: 8208289]

45. Meigs TE, Juneja J, Demarco CT, Stemmle LN, Kaplan DD, Casey PJ. Selective uncoupling of $\mathrm{G} \alpha_{12}$ from Rho-mediated signaling. J Biol Chem 2005;280:18049-18055. [PubMed: 15746095]

46. Offermanns S, Mancino V, Revel JP, Simon MI. Vascular system defects and impaired cell chemokinesis as a result of $\mathrm{G} \alpha_{13}$ deficiency. Science 1997;275:533-536. [PubMed: 8999798]

47. Gu JL, Muller S, Mancino V, Offermanns S, Simon MI. Interaction of $\mathrm{G} \alpha_{12}$ with $\mathrm{G} \alpha_{13}$ and $\mathrm{G} \alpha_{\mathrm{q}}$ signaling pathways. Proc Natl Acad Sci U S A 2002;99:9352-9357. [PubMed: 12077299]

48. Tesmer V, Kawano T, Shankaranarayanan A, Kozasa T, Tesmer JJG. Snapshot of activated G proteins at the membrane: the $\mathrm{G} \alpha_{\mathrm{q}}$-GRK2-G $\beta \gamma$ complex. Science. 2005In press 

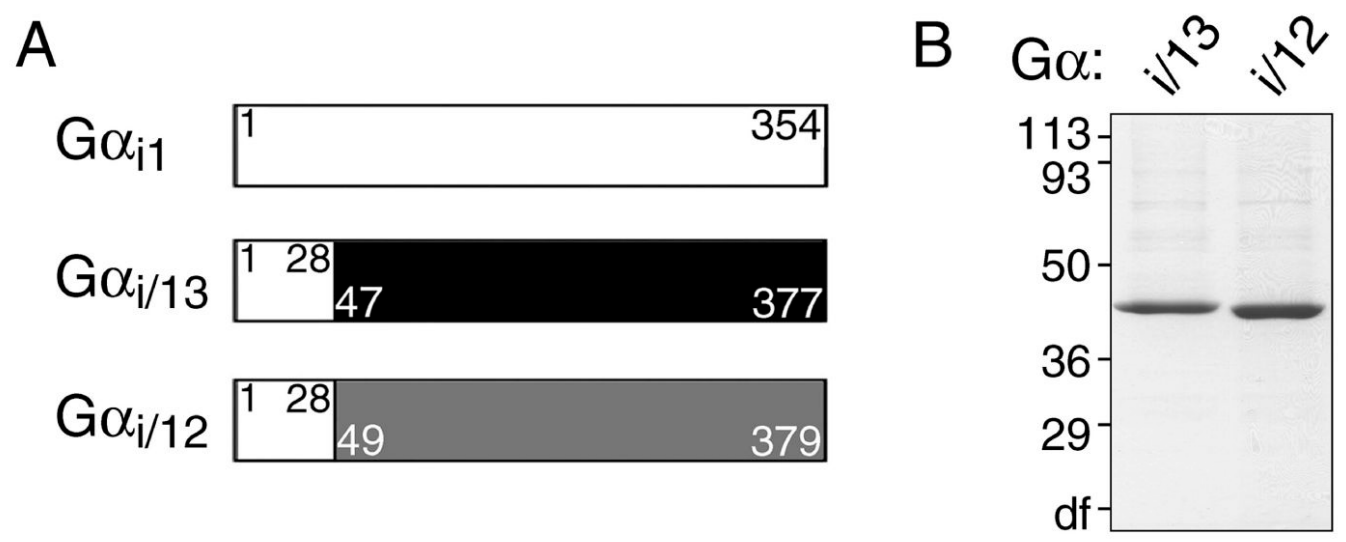

C

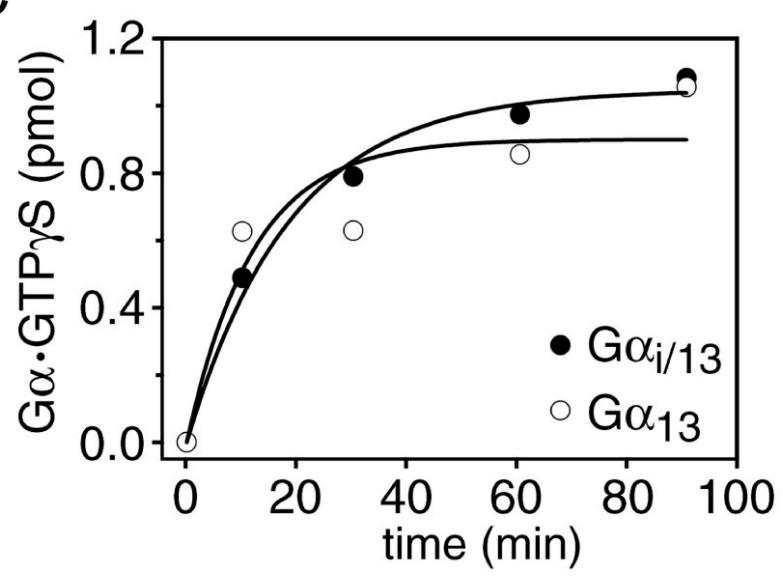

$D$

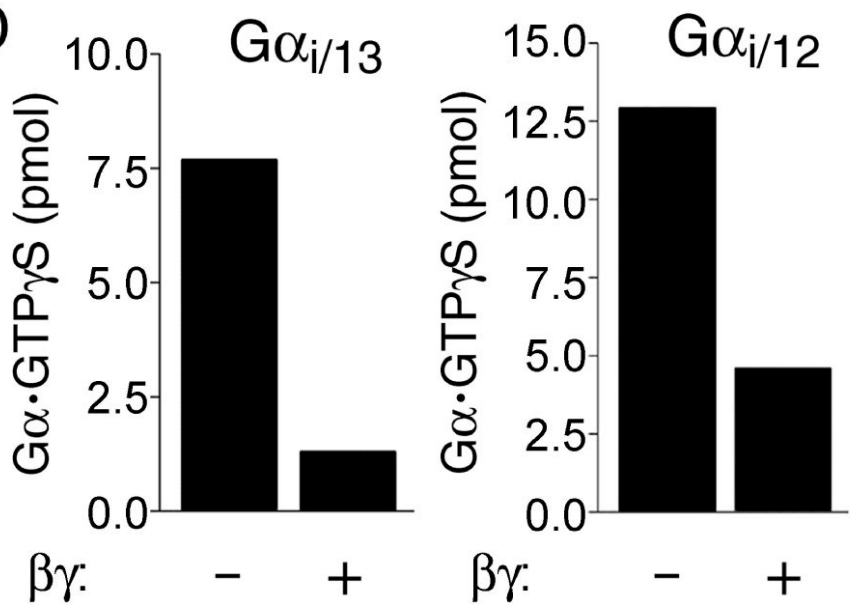

Figure 1.

Generation of $G \alpha_{\mathrm{i} / 13}$ and $\mathrm{G} \alpha_{\mathrm{i} / 12}$ chimeric proteins. (A) Schematic representation of the $\mathrm{G} \alpha_{\mathrm{i} / 13}$ and $\mathrm{G} \alpha_{\mathrm{i} / 12}$ chimera. Residues of $\mathrm{G} \alpha_{\mathrm{i} 1}$ are shown in white, and numbers within the colored regions of the $\mathrm{G} \alpha_{\mathrm{i} / 13}$ or $\mathrm{G} \alpha_{\mathrm{i} / 12}$ chimera correspond to original numbering of residues contributed by $\mathrm{G} \alpha_{13}$ (black) or $\mathrm{G} \alpha_{12}$ (gray). (B) Purified $\mathrm{His}_{6}-\mathrm{G} \alpha_{\mathrm{i} / 13}$ or $\mathrm{His}_{6}-\mathrm{G} \alpha_{\mathrm{i} / 12}(3 \mu \mathrm{g}$ ) were subjected to SDS-PAGE and stained with Coomassie Brilliant Blue. The position and apparent molecular weight of standard proteins (in $\mathrm{kDa}$ ) is indicated. (C) GTP $\gamma \mathrm{S}$ binding to $\mathrm{G} \alpha_{\mathrm{i} / 13}(\bullet)$ or wild-type $\mathrm{G} \alpha_{13}(\circ)$ was measured at $30^{\circ} \mathrm{C}$. Data are the mean of duplicate determinations. (D) $\mathrm{G \alpha}_{\mathrm{i} / 13}$ or $\mathrm{G \alpha}_{\mathrm{i} / 12}$ functionally interact with $\mathrm{G} \beta \gamma$. GTP $\gamma \mathrm{S}$ binding to $\mathrm{G} \alpha_{\mathrm{i} / 13}$ or $\mathrm{G}_{\mathrm{i} / 12}(3 \mu \mathrm{g}$ each) was measured either in the absence or presence of $\mathrm{G} \beta \gamma(20 \mu \mathrm{g})$ as indicated. GTP $\gamma \mathrm{S}$ binding was quantified after $90 \mathrm{~min}$ at $30^{\circ} \mathrm{C}$. Data are the mean of duplicate determinations. 


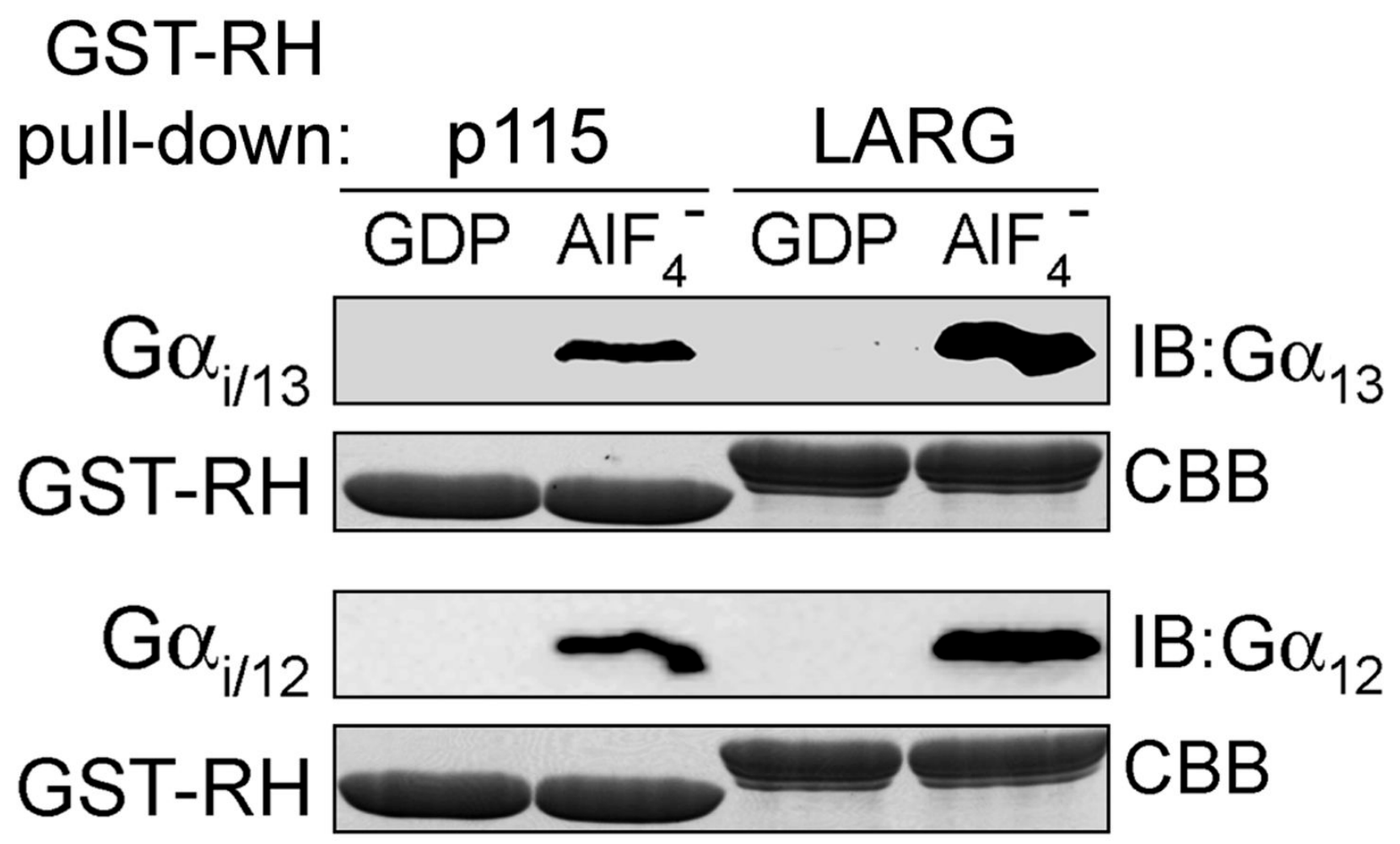

Figure 2.

$\mathrm{G} \alpha_{\mathrm{i} / 13}$ or $\mathrm{G \alpha}_{\mathrm{i} / 12}$ chimera interact with RH domains in an activation-dependent manner. GSTp115-RH or GST-LARG-RH were incubated with purified $\mathrm{His}_{6}-\mathrm{G} \alpha_{\mathrm{i} / 13}$ (upper panels) or $\mathrm{His}_{6}-\mathrm{G \alpha}_{\mathrm{i} / 12}$ (lower panels), either in the absence or presence of $\mathrm{AlF}_{4}{ }^{-}$, and then GST-RH was pulled down using glutathione Sepharose 4B resin. Protein eluted from washed beads was resolved by SDS-PAGE and either immunoblotted (IB) with anti-G $\alpha_{13}$ (B860) or anti-G $\alpha_{12}$ (J168) antibody, or stained by Coomassie Brilliant Blue (CBB). 

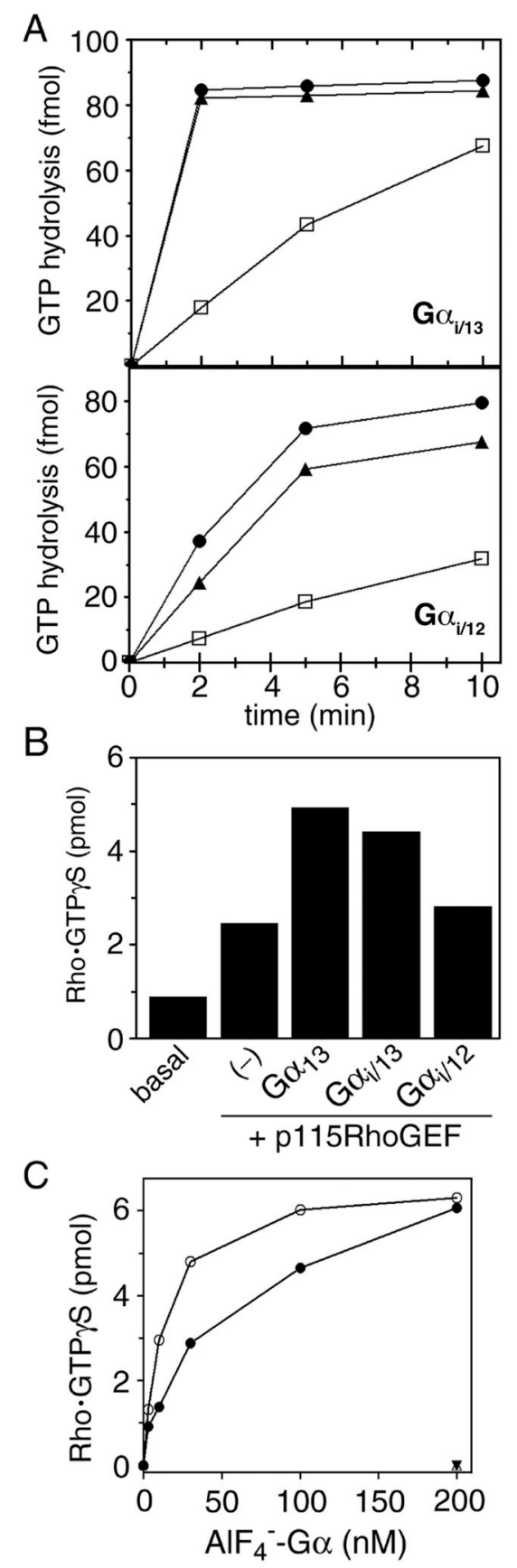

Figure 3.

Activity of purified $\mathrm{G} \alpha_{\mathrm{i} / 13}$ and $\mathrm{G} \alpha_{\mathrm{i} / 12}$ in reconstitution assays. (A) Single-turnover hydrolysis of GTP bound to $\mathrm{G} \alpha_{\mathrm{i} / 13}$ (upper panel) or $\mathrm{G} \alpha_{\mathrm{i} / 12}$ (lower panel) was measured at $15^{\circ} \mathrm{C}$ in the absence $(\square)$ or presence of 100 nM GST-p115-RH (•) or 100 nM GST-LARG-RH ( $\mathbf{\Delta}$ ). Data are from one experiment, which is representative of three experiments. (B) Stimulation of p115RhoGEF activity by $\mathrm{G}_{\mathrm{i} / 13}$ but not $\mathrm{G}_{\mathrm{i} / 12}$. GTP $\gamma \mathrm{S}$ binding to His 6 -RhoA was measured after incubation for $5 \mathrm{~min}$ at $30^{\circ} \mathrm{C}$ in the presence of p115RhoGEF $(5 \mathrm{nM})$ and indicated $\mathrm{AlF}_{4}{ }^{-}$-activated $\mathrm{G} \alpha$ subunit $(100 \mathrm{nM})$. Data are the mean of duplicate determinations from one experiment, which is representative of three experiments. (C) Dose-dependent stimulation of p115RhoGEF activity by $\mathrm{G}_{\mathrm{i} / 13}$. GTP $\gamma \mathrm{S}$ binding to His 6 -RhoA by p115RhoGEF (5 nM) was 
evaluated after $5 \mathrm{~min}$ at $30^{\circ} \mathrm{C}$, and included the indicated concentration of either $\mathrm{AlF}_{4}{ }^{-}$activated wild-type $\mathrm{G \alpha}_{13}(\circ)$ or $\mathrm{Ga}_{\mathrm{i} / 13}(\bullet)$. Samples lacking RhoA but containing $\mathrm{p} 115 \mathrm{RhoGEF}$ and either $\mathrm{AlF}_{4}^{-}$-activated wild-type $\mathrm{G \alpha}_{13}(\Delta)$ or $\mathrm{Go}_{\mathrm{i} / 13}(\boldsymbol{\nabla})$ were assayed in parallel. 

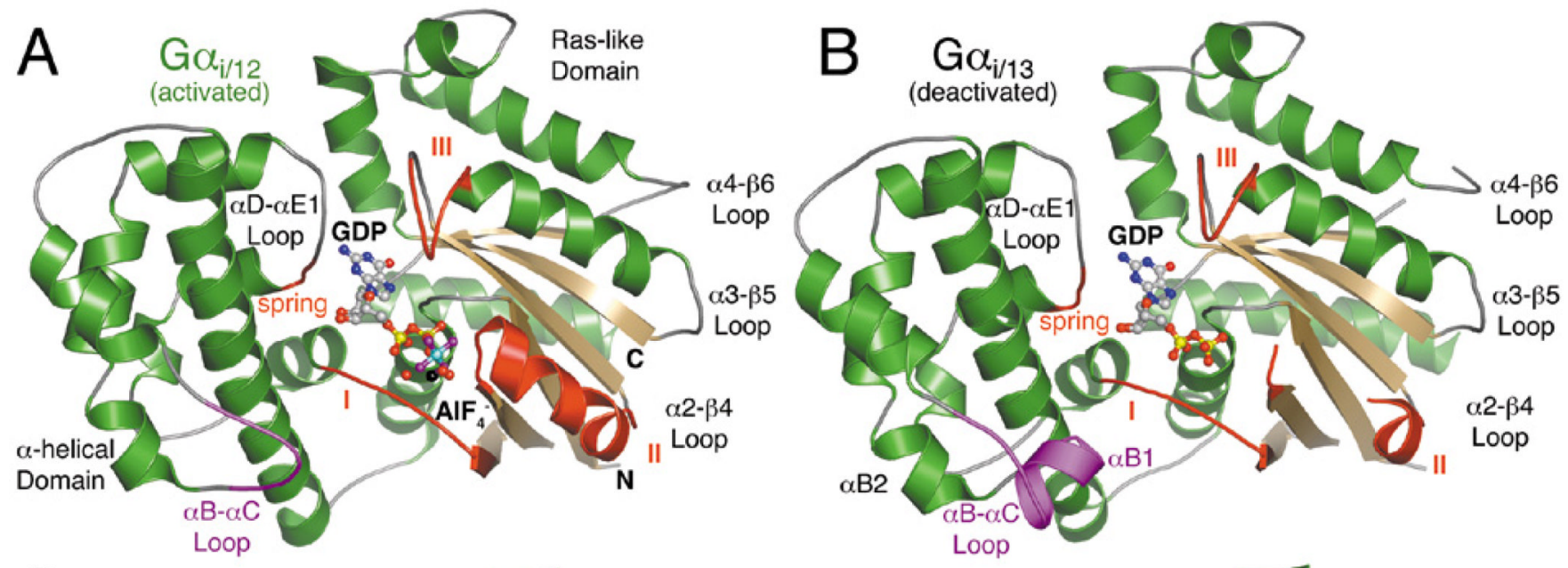

$\mathrm{C}$

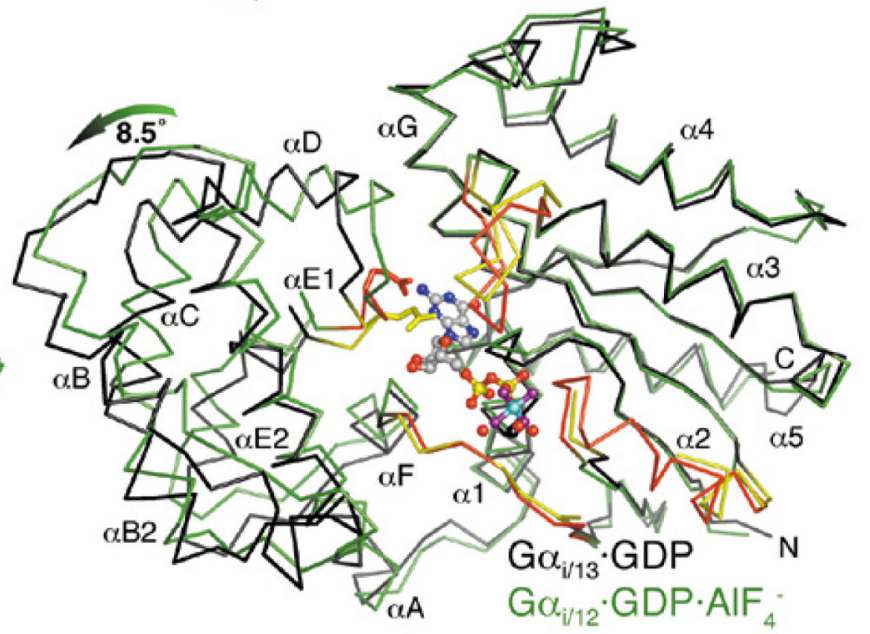

Figure 4.

Structures of $\mathrm{G} \alpha_{12 / 13}$ subunits in activated and deactivated states. (A) The activated $\mathrm{G} \alpha_{\mathrm{i} / 12} \cdot \mathrm{GDP} \cdot \mathrm{AlF}_{4}{ }^{-}$complex. The region of the $\alpha \mathrm{B}-\alpha \mathrm{C}$ loop distinct from that of $\mathrm{G \alpha}_{\mathrm{i} / 13}$ is colored purple. The three conformationally flexible "switch regions" of the G $\alpha$ subunit are red and labeled with Roman numerals (I-III). A fourth, apparently $\mathrm{G}_{12} / 13$-specific element (the "spring") is likewise colored red. The $\mathrm{Mg}^{2+}$. GDP. $\mathrm{AlF}_{4}{ }^{-}$ligand complex is shown as a balland-stick model, with carbons colored gray, oxygens red, nitrogens blue, phosphates yellow, fluorines purple, aluminum cyan and magnesium black. Waters are shown as red spheres. (B) The deactivated $\mathrm{G}_{\mathrm{i} / 13}$. GDP complex adopts an unusually open conformation in which the $\alpha$ helical domain has rotated $\sim 8.5^{\circ}$ away from the Ras-like domain. Switch II is almost completely disordered, and switch III has rotated away (up in the figure) from the nucleotide binding site. (C) Stereo view of the $\mathrm{C}^{\alpha}$ traces of $\mathrm{G} \alpha_{\mathrm{i} / 12} \cdot \mathrm{GDP} \cdot \mathrm{AlF}_{4}{ }^{-}$(green with red switch regions) and $\mathrm{G} \alpha_{\mathrm{i} / 13}$. GDP (black with yellow switch regions), superimposed using their Ras-like domains. The glutamate side chain in the "spring" of each $\alpha$-helical domain (E175 in G $\alpha_{12}$, E172 in $\left.\mathrm{G}_{13}\right)$ is shown as a stick model. 

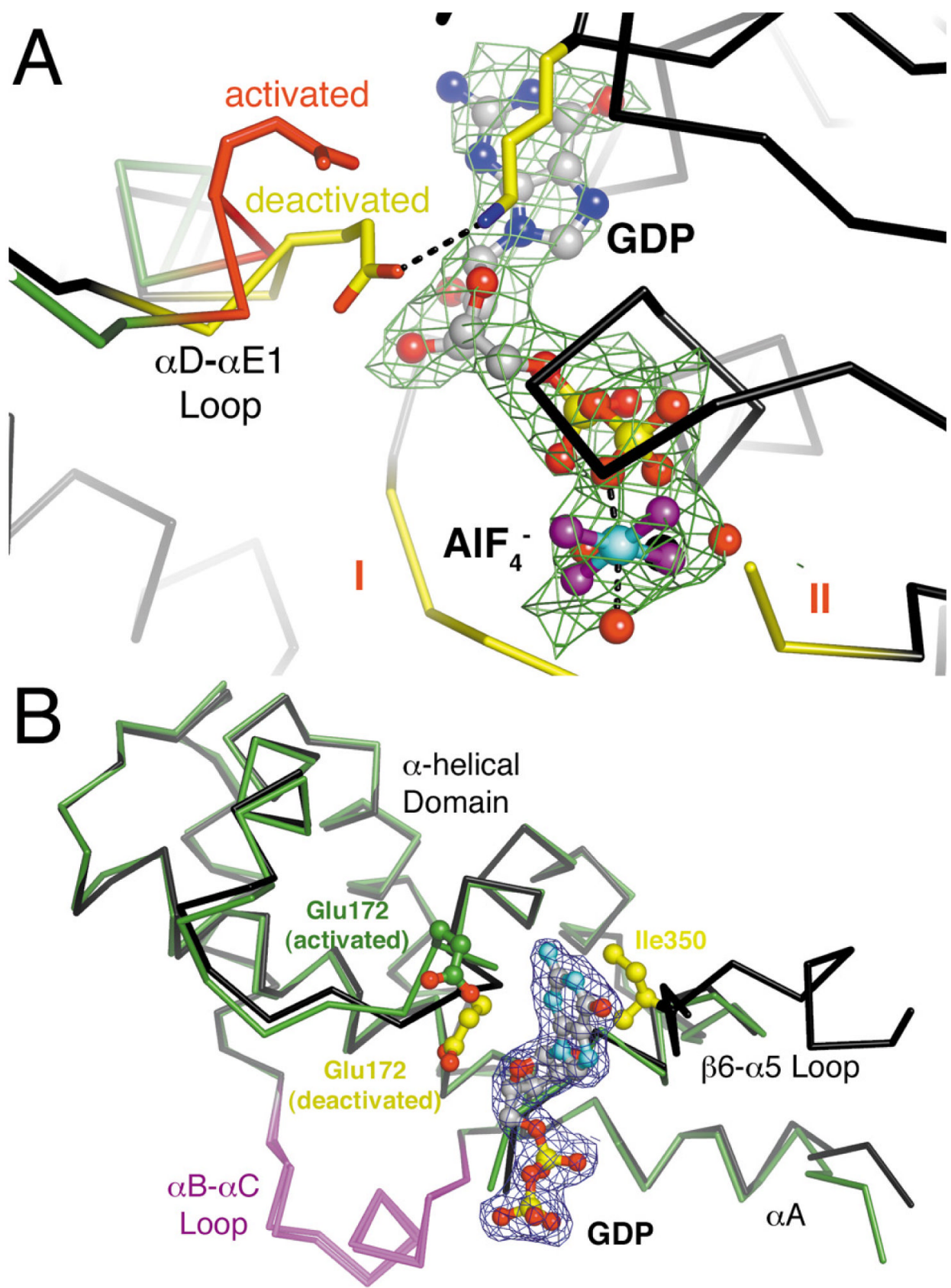

Figure 5.

The active sites and $\alpha$-helical domains of activated and deactivated $\mathrm{G} \alpha_{12 / 13}$ subunits. (A) The activation-dependent "spring" of the $\alpha$-helical domain. In the deactivated (GDP-bound) state, $\mathrm{G \alpha}_{\mathrm{i} / 13}$-E172 (yellow) is extended to form a salt bridge with Lys292 and packs against the nucleotide. In the activated ( $\mathrm{AlF}_{4}{ }^{-}$-bound) state, the spring (red) adopts a curled conformation and $\mathrm{Ga}_{\mathrm{i} / 12}$-Glu175 does not contact the bound nucleotide. Only the Ras-like domain of $\mathrm{G} \alpha_{\mathrm{i} / 13}$ is shown for clarity. Electron density from a $2.5 \sigma\left|\mathrm{F}_{\mathrm{o}}\right|-\left|\mathrm{F}_{\mathrm{c}}\right|$ omit map from the $\mathrm{Go}_{\mathrm{i} / 12} \cdot \mathrm{GDP} \cdot \mathrm{AlF}_{4}{ }^{-}$crystal structure is shown as green wire cage. (B) Superposition of the activated and deactivated conformations of the $\mathrm{G} \alpha_{13} \alpha$-helical domain. The $\mathrm{C}^{\alpha}$-trace of the $\alpha$ helical domain (residues 74 to 201) and the $\beta 6-\alpha 5$ loop (residues 345 to 357) of the 
$\mathrm{G} \alpha_{\mathrm{i} / 13}$.GDP structure are colored black, and the $\alpha$-helical domain from the $\mathrm{G}_{13 / i}-5 \cdot \mathrm{p} 115 \mathrm{RhoGEF}$ complex is colored green. The $\alpha \mathrm{D}-\alpha \mathrm{E} 1$ loop in the $\alpha$-helical domain and the linker between the Ras-like and $\alpha$-helical domains (N-terminal to $\alpha \mathrm{A}$ ) exhibit the most profound conformational changes upon nucleotide hydrolysis. Electron density from a $1.0 \sigma$ $2\left|\mathrm{~F}_{\mathrm{o}}\right|-\left|\mathrm{F}_{\mathrm{c}}\right|$ map derived from the $\mathrm{G} \alpha_{\mathrm{i} / 13} \cdot \mathrm{GDP}$ crystal structure is shown as green wire cage. 
Table I

Crystallographic data and refinement statistics

\begin{tabular}{|c|c|c|}
\hline X-ray Source: APS 17-ID & $\mathbf{G} \alpha_{\mathrm{i} / 12} \cdot \mathbf{G D P} \cdot \mathrm{AlF}_{4}^{-}$ & $\mathbf{G} \boldsymbol{\alpha}_{\mathrm{i} / 13} \cdot \mathbf{G D P}$ \\
\hline Wavelength $(\AA)$ & 1.000 & 1.000 \\
\hline$D_{\min }(\AA)$ & $2.9^{a}$ & 2.0 \\
\hline Space group & $\mathrm{P} 2_{1}$ & $\mathrm{P}_{3}{ }_{3}{ }_{1} 2$ \\
\hline Cell constants $\left(\AA{ }^{\circ},{ }^{\circ}\right)$ & $\begin{array}{l}\mathrm{a}=57.5, \mathrm{~b}=85.2, \mathrm{c}=82.9 ; \beta=106.1, \alpha= \\
\gamma=90\end{array}$ & $\mathrm{a}=\mathrm{b}=67.4, \mathrm{c}=175.2 ; \alpha=\beta=\gamma=90$ \\
\hline Unique reflections & $15263(1140)^{c}$ & $27297(2761)^{c}$ \\
\hline Average redundancy & $2.5(1.7)$ & $5.7(4.0)$ \\
\hline$R_{\mathrm{sym}}(\%)^{b}$ & $10.2(29.6)$ & $4.9(38.5)$ \\
\hline Completeness (\%) & $88.7(67.4)$ & $96.7(100)$ \\
\hline$\langle\mathrm{I}\rangle \mid\left\langle\sigma_{\mathrm{I}}\right\rangle$ & $6.9(1.7)$ & $42.6(3.4)$ \\
\hline Refinement resolution $(\AA)$ & $29.1-2.9$ & $28.5-2.0$ \\
\hline Total reflections used & 14,452 & 25,848 \\
\hline Protein atoms & 5239 & 2618 \\
\hline Non-protein atoms & 74 & 80 \\
\hline RMSD bond lengths $(\AA)$ & 0.007 & 0.015 \\
\hline RMSD bond angles $\left({ }^{\circ}\right)$ & 1.0 & 1.5 \\
\hline $\mathrm{R}_{\mathrm{work}} d$ & $23.9(35.1)^{e}$ & $20.7(24.4)^{e}$ \\
\hline $\mathrm{R}_{\text {free }} \stackrel{f}{f}$ & $29.6(44.3)$ & $25.2(29.4)$ \\
\hline
\end{tabular}

\footnotetext{
${ }^{a}$ Diffraction from this crystal form was anisotropic, with maxima extending beyond $2.9 \AA$ in the $b^{*}$ direction, and from $3.5-4.5 \AA$ in orthogonal directions.

$b_{\mathrm{R}}{ }_{\mathrm{sym}}=\sum \mathrm{h} \sum_{\mathrm{i}} \mid \mathrm{I}(\mathrm{h})_{\mathrm{i}}-\mathrm{I}(\mathrm{h}) / / \sum \mathrm{h} \sum \mathrm{i} \mathrm{I}(\mathrm{h}) \mathrm{i}$, where $\mathrm{I}(\mathrm{h})$ is the mean intensity of $i$ reflections after rejections. A $-0.5 \mathrm{I} / \sigma \mathrm{I}$ cutoff was applied to the $\mathrm{G} \alpha_{\mathrm{i}} / 12$ data set due to its anisotropic data.

${ }^{c}$ Numbers in parentheses correspond to the highest resolution shell of data for each set, which was $3.0-2.9 \AA$ for $\mathrm{G} \alpha_{\mathrm{i}} / 12$ and $2.07-2.00 \AA$ for $\mathrm{G} \alpha_{\mathrm{i} / 13}$.

$d_{\mathrm{R}_{\mathrm{Work}}}=\sum \mathrm{hkl}|| F_{\mathrm{obs}}(h k l)|-| F_{\mathrm{calc}}(h k l) \| / \sum \mathrm{hkl}\left|F_{\mathrm{Obs}}(\mathrm{hkl})\right| ;$ no I/ $\sigma$ cutoff was used during refinement.

${ }^{e}$ Numbers in parentheses correspond to the highest resolution shell of data for each set, which was $3.0-2.9 \AA$ for $\mathrm{G \alpha} \mathrm{i} / 12$ and $2.05-2.00 \AA$ for $\mathrm{G} \alpha_{\mathrm{i}} / 13$.

$f_{5 \% \text { of the truncated data set was excluded from refinement to calculate } \mathrm{R} \text { free. }}$
} 